\title{
CURRENT TRENDS OF REFORMING THE SYSTEM OF SENTENCE ENFORCEMENT IN THE FORM OF DEPRIVATION OF FREEDOM FOR DETERMINED PERIOD IN UKRAINE
}

\author{
Vasylyk V. V., Oliinyk O. I.
}

\section{INTRODUCTION}

The development of Ukraine as a state governed by the rule of law, the main duty of which is to affirm and ensure human rights and freedoms, requires a radical change in the priorities of penal bodies and institutions. First of all, it is necessary to humanize and bring the national rules for the treatment of convicts in accordance with international and European standards. Such a transformation aims not only to increase the efficiency of the relevant state institutions, but above all, to ensure the observance of the rights of those persons against whom sentences are executed. This strategic direction of the state's activity provides for a qualitative change in Ukraine's legislation, reforming the entire system of penal bodies and institutions, in particular, changes in the activities of state penal bodies, which necessitates updating their theoretical and methodological foundation.

Today, in this area, there are scientific developments of such domestic scholars in the field of criminal and executive law as: K.A. Avtukhov, A.V. Betsa, V.A. Badyra, O.M. Dzhuzha, O.H. Kolb, N.V. Kolomiiets, V.Ya. Konopelskyi, I.M. Kopotun, V.O. Korchynskyi, V.O. Merkulova, M.S. Puzyrov, A. Kh. Stepaniuk, V.M. Trubnykov, S.Ya. Fareniuk, V.P. Filonov, O.I. Frolov, S.V. Tsariuk, Yu.V. Shynkariov, O.O. Shkuta, D.V. Yahunov, I.S. Yakovets, and others.

At the same time, in modern conditions, taking into account the abovementioned prospects for the development of penitentiary theory and practice, issues related to reforming the system of sentence enforcement in the form of deprivation of freedom for determined period are relevant. The choice of this type of punishment is predetermined by a number of circumstances due to the standpoint of criminal and executive policy forming and implementing.

Firstly, the process of sentence enforcement in the form of deprivation of freedom for determined period has the highest degree of legal regulation, compared to the other types of punishments, and is applied to a significant number of persons guilty of criminal offenses. In particular, according to court statistics, in 201144,201 persons were sentenced to deprivation of freedom for determined period in the state (that was $28.64 \%$ of the total number of convicts), in 2012 there were 42,938 persons $(26.36 \%)$, in 2013 there were 30,479 persons $(24.79 \%)$, in 2014 there were 20,872 persons $(20.43 \%)$, in 2015 there were 19,765 persons $(21.0 \%)$, in 2016 there were 16,140 persons $(21.2 \%)$, in 2017 there were 16,143 persons $(21.2 \%)$, in 2018 there were 13,765 persons 
$(18.7 \%)^{1}$. Despite the dynamics of reducing the number of convicts, this type of punishment is firmly in the "top three" of criminal sanctions for committing criminal offenses (after such sanctions as: release from probation and a fine, occupying the first and second positions, accordingly). It takes the first place in quantitative terms, among those punishments that take place in conditions of social isolation and are executed by the State Criminal and Executive Service (SCES) of Ukraine (arrest, restriction of freedom, life sentence), as evidenced by official statistics of the penitentiary department.

Secondly, serving a sentence in the form of deprivation of freedom for determined period provides for the possibility for the administration to give a flexible response to convicts' behavior in order to prevent them from violating the requirements of the regime. However, the existing measures of punitive and corrective influence on convicts, the order of executing and serving sentences, etc., inherited from the Soviet correctional-labor system, are ineffective and do not meet modern world standards.

Also, the need for using progressive forms and methods of social-educational and individual-preventive work is predetermined by the complex criminogenic convicts' nature. As of 01.01.2020 it is represented by the following indicators: 5,153 persons are sentenced to more than 10 years; 6,555 persons are sentenced for premeditated murder; 2,862 persons are sentenced for inflicting intentional grievous bodily harm; 6,989 persons are sentenced for robbery and burglary; 11,797 persons are sentenced for theft; 629 persons are sentenced for rape; 12 persons are sentenced for crimes against the foundations of national security ${ }^{2}$.

\section{The current state of criminal and executive legislation on sentence enforcement in the form of deprivation of freedom for determined period}

The current state of the criminal and executive legislation of Ukraine on sentence enforcement in the form of deprivation of freedom for determined period has undergone a long path of rule-making evolution, which resulted in the development and adoption of the Criminal Executive Code (CEC) of Ukraine in $2003^{3}$.

O.I. Oliinyk, a domestic expert in the field of history of law, rightly points out, that adopted by the Verkhovna Rada of Ukraine on July 11, 2003, the CEC of Ukraine, which entered into force on January 1, 2004, received generally positive assessment from both domestic scholars and practitioners and by experts of the

\footnotetext{
${ }^{1}$ Судова статистика. Аналітичні огляди щодо стану здійснення правосуддя. Судова влада Украӥни. URL : https://court.gov.ua/inshe/sudova_statystyka/ (дата звернення: 20.05.2020).

2 Загальна характеристика Державної кримінально-виконавчої служби України. URL : https://kvs.gov.ua/ 2020/harakteristika/01.02.2020.pdf (дата звернення: 20.05.2020).

${ }^{3}$ Кримінально-виконавчий кодекс України: Закон України від 11.07.2003 p. № 1129-IV. Biдомості Верховної Ради України. 2004. № 3-4. Ст. 21.
} 
international community and can rightly be considered a significant step forward for our state in the direction of approximation to the requirements and rules of international standards in the field for the treatment of convicts ${ }^{4}$.

At the same time, as evidenced by the progressive development of domestic legal reality, having received a progressive and humane CEC of Ukraine in 2003, the penitentiary system has not suspended the search for improvement. Since 2005, the codification act has been amended by more than 30 laws. A significant part of them relate to the procedure and conditions of sentence enforcement in the form of deprivation of freedom for determined period.

Therefore, we want to pay attention to the main ones regarding the regulation of the institution of execution in the form of deprivation of freedom for determined period, depending on the subject of the legislative initiative, which at one stage or another acted as a penitentiary agency in one form or another. Therefore, we distinguish the following periods:

I. Period of penitentiary legislation (January 1, 2004 - December 9, 2010), initiated by the State Department of Ukraine for the Execution of Sentences. During the work of this authority the CEC of Ukraine was undergone the following progressive changes in the procedure and conditions of executing and serving a sentence in the form of deprivation of freedom for determined period:

1) making amendments to the legal regulation of functioning a section of enhanced control of correctional colonies (Part 4 of Article 94, Article 97)

2) humanizing conditions of convicts' detention in a social rehabilitation unit (Part 2 of Article 99) ${ }^{6}$;

3 ) improving the procedure for convicts to pursue legitimate interests by giving convicts the right to apply to the administration in order to submit a motion for parole or replace the unserved part of the sentence with a milder sentence (supplement to Part 1 of Article 107 of the CEC of Ukraine, Paragraph 16) ${ }^{7}$;

4) granting to convicts who work and serve their sentences in correctional colonies of a minimum security level with facilitated conditions of detention, the right to maintain an annual short-term departure from the colony lasting 14 calendar days (Part 4 of Article 111);

5) making abolition of restrictions on the number of parcels (packages) and letter packets received by convicts (Part 1 of Article 112, amendments to Parts

\footnotetext{
${ }^{4}$ Олійник О.І. Загальна характеристика періодів становлення та розвитку кримінально-виконавчої системи і законодавства України. Кримінально-виконавчому кодексу Украӥни - 9 років: матеріали I міжнар. наук.-практ. конф. (Київ, 28 листоп. 2012 р.). Київ : Інститут кримінально-виконавчої служби, 2012. С. 17.

${ }^{5}$ Про внесення змін до Кримінально-виконавчого кодексу України щодо забезпечення прав засуджених осіб в установах виконання покарань: Закон України від 21.01.2010 p. № 1828-VI. Відомості Верховної Ради Украӥни. 2010. № 12. Ст. 114.

${ }^{6}$ Там само.

7 Там само.

8 Там само.
} 
one of Articles 138 and 139, Part 2 of Article 140, Part 1 of Article 143, Part 5 of Article 151) ${ }^{9}$;

6) improving the mechanism for convicts' addressing correspondence to the European Court of Human Rights, as well as to other relevant bodies of international organizations in which Ukraine is a member or participant (Part 4 of Article 113$)^{10}$;

7) introducing a system of holding convicts in block-type premises, increasing the norm of living space per a convict (Part 1 of Article 115) ${ }^{11}$;

8) imposing the administration with the obligation to create conditions that allow convicts to engage in socially useful paid work (supplement to the relevant norm (Paragraph 2), Part 1 of Article 118) ${ }^{12}$;

9) providing convicts who do not have a working profession, for which they can be employed in this colony, the opportunity to train in vocational training courses for workers in the workplace (until 2010, this type of training was convict's duty) (Part 4 of Article 125) ${ }^{13}$;

10) excluding appointment to an extraordinary duty to clean the premises and territory of the colony from the system of penalties applicable to convicts (Part 1 of Article 132) ${ }^{14}$;

11) humanizing the legal status of convicted women (Parts 1, 2, 3 of Article 141$)^{15}$.

II. Period of improving the criminal and executive legislation under the aegis of the State Penitentiary Service of Ukraine (December 9, 2010 - May 18, 2016). During this period the following progressive steps were achieved in the field of executing and serving a sentence in the form of deprivation of freedom for determined period:

1) further humanizing of the legal status of convicted women who have children under the age of three, and the legal regime of orphanages functioning in correctional colonies (Parts 1, 5, 7 of Article 141) ${ }^{16}$;

\footnotetext{
${ }^{9}$ Про внесення змін до Кримінально-виконавчого кодексу України щодо забезпечення прав засуджених осіб в установах виконання покарань: Закон України від 21.01.2010 р. № 1828-VI. Відомості Верховної Ради України. 2010. № 12. Ст. 114.

${ }^{10}$ Про внесення змін до деяких законодавчих актів України щодо забезпечення права засуджених і осіб, які тримаються під вартою, на листування з питань, пов’язаних з порушенням прав людини: Закон України від 01.12.2005 р. № 3166-IV. Відомості Верховної Ради Украӥни. 2006. № 12. Ст. 103.

11 Про внесення змін до Кримінально-виконавчого кодексу України щодо забезпечення прав засуджених осіб в установах виконання покарань: Закон України від 21.01.2010 p. № 1828-VI. Biдомості Верховної Ради Украӥни. 2010. № 12. Ст. 114.

12 Там само.

13 Там само.

${ }^{14}$ Там само.

15 Там само.

${ }^{16}$ Про внесення змін до Кримінально-виконавчого кодексу України щодо порядку та умов відбування покарання: Закон України від 05.09.2013 р. № 435-VII. Відомості Верховної Ради Украӥни. 2014. № 20-21. Ст. 724.
} 
2)humanizing the legal status of convicted juveniles by: 1) abolishing restrictions on obtaining short-term visits (until September 5, 2013 provided for one short-term visit per month) and increasing the number of long-term visits (thus, until September 5, 2013 in juvenile correctional colonies convicts had the right to receive a long-term visit once every three months, and starting from September 5, 2013 they have the right to receive one long-term visit per month) (Paragraph 3, Part 1 of Article 143); 2) providing an opportunity to implement such a form of improvement detention conditions as receiving a short-term visit outside the juvenile correctional colony once every three months by the decision of the colony chief for conscientious behavior and attitude to work and study after serving at least one quarter of the sentence ${ }^{17}$;

3) making amendments to the criminal and executive legislation of Ukraine on adaptation of convict's legal status to European standards in the following areas:

- increasing the personal responsibility of the head of a penal institution for the accommodation of convicts who arrived at the institution (Part 6 of Article 8 of the CEC of Ukraine); 2) separate detention of persons suffering from tuberculosis from other prisoners (Part 1 of Article 21); 3) extension of the list of officials authorized without special permission (accreditation) to visit unimpeded penal institutions at any time in order to maintain control and inspections (Article 24); 4) changing the legal nature (out of legitimate interest into the convicts' right) of the institute to change the conditions of detention convicts sentenced to imprisonment (Paragraph 1, Part 1 of Article 101); 5) changes in the list of categories of persons who are not subjected to being transferred to the section of social rehabilitation (Part 2 of Article 101); 6) improving the procedure for prisoners to exercise the right to receive medical care and treatment (Paragraph 5, Part 1 of Article 107), as well as providing convicts with short-term trips outside correctional and juvenile correctional colonies to receive medical care, if such care cannot be provided on the territory of the relevant place of imprisonment (Supplement to Part 1 of Article 111, Paragraph 4); 7) improving the algorithm of realization convicts' right to contacts with the outside world at the expense of addition of the Paragraph 7, Part 1 of Article 107 of the CEC of Ukraine, the right to have telephone conversations with the persons outside the colonies in mobile networks, to use the global Internet; making appropriate changes to Article 110 of the CEC of Ukraine; 8) differentiation of the number and types of convicts' visits depending on the type of structural unit of the colony (Part 4 of Article 110); 9) changing the legal nature (out of legitimate interest into the convicts' right) of the institute of short-term trips outside correctional and juvenile correctional colonies (Paragraph 1, Part 1 of Article 111); 10) changing the legal nature (out

\footnotetext{
${ }^{17}$ Про внесення змін до Кримінально-виконавчого кодексу України щодо порядку та умов відбування покарання: Закон України від 05.09.2013 р. № 435-VII. Відомості Верховної Ради Украӥни. 2014. № 20-21. Ст. 724.
} 
of duty into the convicts' right) of convicts' work (Part 1 of Article 118); 11) supplementing the list of rights of convicted juveniles with the right to receive secondary education free of charge (Paragraph 5, Part 1 of Article 143); 12) improving the procedure (with defining its mandatory nature) of full settlement with a person who is released from serving a sentence (Part 3 of Article 153); 13) improving the procedure for early parole on the grounds provided with Articles 81, 82 of the Criminal Code (CC) of Ukraine (Part 3 of Article 154); 14) changing the discretionary procedure to the mandatory procedure for release women sentenced to imprisonment who became pregnant or gave birth to children while serving their sentences (Paragraph 1, Part 10 of Article 154) ${ }^{18}$;

- introducing pastoral care of convicts (Supplement of the CEC of Ukraine with the same article 128-1) ${ }^{19}$.

III. Period of reforming (developing) the penitentiary system under the aegis of the Ministry of Justice of Ukraine (May 18, 2016 - present day). On the basis of the analysis of normative-legal maintenance of sentence enforcement in the form of deprivation of freedom for determined period there are bases to make the following generalizations concerning the measures taken by the Ministry of Justice of Ukraine in order to improve this legal institution:

1) making amendments to the criminal and executive legislation of Ukraine to improve the procedure for applying measures of encouragement and punishment to convicts in the following areas: 1) extension of the system of encouragement measures applied to persons deprived of liberty (Part 1 of Article 130 of the CEC of Ukraine); 2) imposing on the administration of a colony the obligation to conduct a quarterly assessment of person's behavior, compliance with the rules of conduct established by the CEC of Ukraine and the rules of procedure of a colony (Part 8 of Article 131); 3) supplementing the CEC of Ukraine with the norms that determine the legal nature of disciplinary misconduct (Article 131-1) and circumstances that exclude disciplinary liability (Article 131-2);4) defining the concept of «malicious violation of the established order of serving a sentence» (Article 133); 5) improving the procedure for applying sanctions to persons deprived of their liberty (Article 134);6) determining the procedure of disciplinary proceedings (Article 135) ${ }^{20}$;

\footnotetext{
${ }^{18}$ Про внесення змін до Кримінально-виконавчого кодексу України щодо адаптації правового статусу засудженого до європейських стандартів: Закон України від 08.04.2014 р. № 1186-VII. Biдомості Верховної Ради Украӥни. 2014. № 23. Ст. 869.

${ }^{19}$ Про внесення змін до деяких законодавчих актів України щодо регулювання діяльності священнослужителів (капеланів) в органах та установах, що належать до сфери управління Державної пенітенціарної служби України: Закон України від 14.05.2015 р. № 419-VIII. Відомості Верховної Ради України. 2015. № 28. СТ. 254.

${ }^{20}$ Про внесення змін до Кримінально-виконавчого кодексу України щодо вдосконалення порядку застосування до засуджених заходів заохочення і стягнення: Закон України від 06.09.2016 p. № 1487-VIII. Відомості Верховної Ради Украӥни. 2016. № 42. Ст. 699.
} 
2) making amendments to the criminal and executive legislation of Ukraine on the humanization of the procedure and conditions of execution of punishments in the following areas: 1) changes in the list of categories of persons who are not subjected of being transferred to the social rehabilitation unit (exclusion of such category are pregnant women and women who have children under the age of three), Part 2 of Article 101 CEC of Ukraine; 2) granting convicts to imprisonment additional rights in the field of health care (Supplement to Article 116 by Parts 6 and 7) ${ }^{21}$;

3) making amendments to the criminal and executive legislation of Ukraine on ensuring the execution of criminal penalties and realization convicts' rights of in the following areas: 1) improving the mechanism of realizing convicts' right to appeal to national and international authorities (Paragraph 4, Part 1 of the Article 8 of the CEC of Ukraine); 2) improving the mechanism of guaranteeing convicts the right to appropriate working conditions (Paragraph 9, Part 1 of Article 8); 3 ) improving the general mechanism for the exercise of convicts' rights through the consolidation of the right to receive copies of documents from their personal files and others related to the exercise of their rights (Paragraph 12, Part 1 of Article 8); 4) improving the procedure for changing the conditions of detention of convicts by consolidating the need to agree on transfers that provide for an increase in the amount of established restrictions and stricter conditions of detention with the supervisory commission (Parts 2, 3 of Article 100); 5) abolishing restrictions on the amount of food and basic necessities, the right to purchase which by non-cash payment have the convicts (Parts 1-6 of Article 108); 6) involving convicts in paid work, as a rule, at enterprises, workshops of colonies, as well as at state or other forms of ownership of enterprises under a fixed-term employment contract concluded between a convict and a correctional colony (pre-trial detention center), provided they are properly protected and insulation (Part 1 of Article 118); 7) increasing the percentage (not less than 50) of the accrued monthly earnings, which is credited regardless of all deductions to the personal account of convicts who are involved in socially useful paid work in correctional colonies (Part 2 of Article 120); 8) abolishing the obligation of persons serving sentences in correctional colonies to reimburse the cost of food, shoes, clothes, linen (Part 1 of Article 121); 9) legislative consolidating the mechanism of compulsory state social insurance and improvement of the procedure for pension provision of convicts (Article 122); 10) removing restrictions on the amount of money earned in the correctional colony, received by transfer, from pensions and other income that convicts in correctional colonies of different levels of security have the right to

\footnotetext{
${ }^{21}$ Про внесення змін до Кримінально-виконавчого кодексу України щодо гуманізації порядку та умов виконання покарань: Закон України від 06.09.2016 р. № 1488-VIII. Відомості Верховної Ради Украӥни. 2016. № 42. Ст. 700.
} 
spend on food, clothing, footwear, linen and basic necessities; 11) bringing the norms of criminal and executive legislation in line with the family law, in particular by giving the child's father, who is placed in the child's home at the correctional colony where the mother is serving her sentence, to influence the child's legal fate (Part 6 of the Article 141 of the CEC of Ukraine); 12) abolishing the restrictions on the amount of money or other income for the purchase of food, clothing, footwear, underwear and basic necessities by convicted minors (Paragraph 2, Part 1 of Article 143); 13) improving the procedure for providing assistance to convicts sentenced to imprisonment for a certain period in employment and living conditions (Part 1 of Article 156); 14) consolidating the legal basis for the implementation of measures for social patronage of persons released from punishment in the form of deprivation of freedom for determined period (Supplement to Article 156, Part 4) ${ }^{22}$.

\section{The main ways to improve the institution of sentence enforcement in the form of deprivation of freedom for determined period}

Today, the penitentiary doctrine holds that criminal and executive policy is determined by criminal policy, and accordingly is a reproduction of the understanding of the effectiveness of certain areas of criminalization and penalization in criminal law, the priority of measures to influence an offender, possibilities (or, conversely, inabilities) to achieve goals punishment, etc. ${ }^{23}$.

While analyzing the current trends of reforming (developing) the penitentiary system, one of the provisions of criminal law, which largely determines the direction of public policy in the field of criminal penalties execution, is the doctrine of the purpose of punishment.

Different positions on this issue gave a domestic scholar I.S. Yakovets grounds to state the existence in Ukraine of two main paradigms of the process of sentence enforcement: 1) correctional - is based on the concept of combining punishment with corrective influence and aims to correct and re-socialize convicts (this paradigm is scientific school of criminal and executive law); 2) criminal-executive - is based on the concept according to which the execution of punishment is to implement its inherent restrictions, and the essence of the activity of execution of punishment is the implementation of punishment (it is substantiated by the Kharkiv Scientific School of Criminal and Executive Law) ${ }^{24}$.

\footnotetext{
22 Про внесення змін до деяких законодавчих актів України щодо забезпечення виконання кримінальних покарань та реалізації прав засуджених: Закон України від 07.09.2016 р. № 1492-VIII. Вiдомості Верховної Ради України. 2016. № 43. Ст. 736.

${ }^{23}$ Гритенко О. А. Теоретико-правові концептуальні засади прогресивної системи виконання та відбування покарання у виді позбавлення волі: дис. ... д-ра юрид. наук: 12.00.08. Одеса, 2020. С. 35.

${ }^{24}$ Яковець I. С. Теоретичні та прикладні засади оптимізації процесу виконання кримінальних покарань: монографія. Харків: Право, 2013. С. 10.
} 
The modern vector of reforming (developing) the penitentiary system under the aegis of the Ministry of Justice of Ukraine testifies to the observance of the specified central body of executive power, which ensures the formation and implementation of state policy in the field of executing criminal punishments, namely the correctional paradigm.

In the context of sentence enforcement in the form of deprivation of freedom for determined period, this paradigm is implemented in the following areas (specified in the Regulation on the Ministry of Justice of Ukraine, the draft Law of Ukraine "On Penitentiary System" 2020 and organically derived from the criminal and executive legislation of Ukraine):

1) ensuring the formation of a system of supervisory, social, educational and preventive measures applicable to convicts;

2) control over observance of human and civil rights, requirements of the legislation on executing and serving of criminal punishments, realization of convicts' legal rights and interests;

3) organizing social, educational and psychological work with convicts, involvement of representatives of religious and charitable organizations, public associations, creative unions, individuals;

4) facilitating the exercise by supervisory commissions and public associations of public control over the observance of convicts' rights and legitimate interests during the execution of criminal sentences;

5) organizing convicts' vocational and technical as well as general education in cooperation with the Ministry of Education and Science.

It should be noted that based on the powers of the Ministry of Justice of Ukraine in the field of sentence enforcement, each area is specified in the functions (powers) of a body (institution) of execution of sentences and further according to the structure - the relevant structural unit, its employees who are responsible for the implementation of a particular direction.

Moreover, the progressive introduction of a correctional paradigm of the process of sentence enforcement in the form of deprivation of freedom for determined period is indicated by the modifying of Part 2 of Article 1 of the draft Law of Ukraine "On the Penitentiary System» in 2020, according to which «the purpose of the penitentiary system is to protect society from crime. The activity of the penitentiary system is not punitive and is aimed at person's re-socialization and re-integration" 25 .

It should be noted that this position of penitentiary rule-making is stable and consistent, given that the previous draft Law "On the Penitentiary System" dated 24.11.2017 № 7337, as enshrined in Part 2 of Article 1 appropriate purpose and

\footnotetext{
${ }^{25}$ Проєкт Закону України «Про пенітенціарну систему». Міністерство юстицї України: офіційний сайт. URL : https://minjust.gov.ua/m/13102020-povidomlennya-pro-provedennya-publichnogo-gromadskogoobgovorennya-proektu-zakonu-ukraini-pro-penitentsiarnu-sistemu (дата звернення: 18.11.2020).
} 
direction of the penitentiary system, also provided in Section VII «Final and Transitional Provisions» a proposal for exclusion the words "not only punishment but also" in Part 2 of Article 50 of the CC of Ukraine (which is devoted to the formulation of the purpose of punishment $)^{26}$. In such circumstances, the updated version of Part 2 of Article 50 of the CC of Ukraine should look like this: "Punishment is aimed at correcting convicts, as well as preventing the commission of new criminal offenses by both convicts and other persons".

The proposal contained in the draft Law "On the Penitentiary System" dated 24.11.2017 № 7337 to supplement Article 73 of the CC of Ukraine, should be evaluated in a positive way concerning stimulating convicts' socially useful employment. It contains the following words: "Persons sentenced to imprisonment for a determined period or life imprisonment who work, the term of punishment is credited at the rate of three working days for four days of serving the sentence. The conditions of such enrollment are established by the Criminal Executive Code of Ukraine"27.

These provisions are of particular importance in view of the recognition, starting in 2014, of the work of persons sentenced to imprisonment as their right and not their duty. Therefore, the relevant legislation, in case of their successful implementation, should stimulate the convict's desire to work while serving his sentence, which will contribute to his correction and re-socialization.

It should be noted that one of the distinguishing features of the draft law "On the Penitentiary System" in 2020 compared to the draft in 2017 is the lack of the first proposals for amendments to the legislation of Ukraine, which relate to various aspects arising in connection with the implementation and serving sentences.

However, this does not mean that after the adoption of the Law of Ukraine "On the Penitentiary System" (as amended in the draft 2020), the relevant changes to regulations (formulated in 2017) should remain out of the attention of the Ukrainian legislator. It will be expedient to envisage them in the draft Law of Ukraine On Amendments to Certain Legislative Acts of Ukraine in Connection with the Adoption of the Law of Ukraine "On the Penitentiary System". This will provide the optimal mechanism for sentence enforcement in the form of deprivation of freedom for determined period in the context of achieving the goal and focus of the penitentiary system on person's re-socialization and re-integration.

In addition to the rules for improving the procedure and conditions of sentence enforcement in the form of deprivation of freedom for determined period, we consider relevant direction of improving the management structure of penal institutions, as direct subjects of the relevant measure of state coercion.

\footnotetext{
${ }^{26}$ Проєкт Закону про пенітенціарну систему: від 24.11.2017 p. № 7337. URL : http://w1.c1.rada.gov.ua/pls/ zweb2/webproc4_1?pf3511=62965 (дата звернення: 20.05.2020).

${ }^{27}$ Там само.
} 
Therefore, having analyzed the problems of modern management practice, we believe that the optimal management structure of the penitentiary system should provide for the establishment in each region of a department (sector) for the execution of criminal penalties, which would be subordinated to the relevant interregional criminal administration of the Ministry of Justice.

It should be noted that currently similar structures at the departmental (sector) level operate at the level of each region, but their functional focus on prompt and timely implementation of tasks on the ground concerns only issues of regime, protection and supervision. At the same time, the range of powers to implement state policy in the field of execution of criminal punishments is wider, and in addition to the relevant regime block includes the organization and conduct of socio-educational and psychological work, operational and investigative activities and more. Therefore, in these structural units at the level of each region should be provided for positions of specialists in all the above areas. This will allow for more consistent implementation in practice (by exercising control by the regional unit over specific areas of penal institutions) of the relevant tasks of the Ministry of Justice of Ukraine, its interregional (Department for the Execution of Criminal Punishments) and territorial bodies ( 5 interregional departments) policies in the field of execution of criminal punishments.

Another aspect that we would like to draw attention to in the context of improving the organizational and legal framework for sentence enforcement in the form of deprivation of freedom for determined period is the feasibility of introducing foreign experience in creating multifunctional (universal) penal institutions in Ukraine, which would combine several levels of security (minimum, average, maximum) or types of institutions (for example, correctional and juvenile correctional colonies through the creation of appropriate isolated sectors).

This proposal is based on a number of preconditions and objective circumstances available at the present stage of the penitentiary system. In particular, it should be noted that currently due to a number of legislative novelties (adoption in 2012 of the new Criminal Procedural Code of Ukraine), expanding the practice of sentencing not related to imprisonment, gradual change of detention conditions within the progressive system of executing/ serving a prison sentence, there was a decrease in the number of convicts in penitentiaries. For example, if in 2012 the number of convicts sentenced to a term of imprisonment who served their sentences in correctional colonies was 100,826 persons $^{28}$. In 2014 there were 85,429 persons $^{29}$ and in 2020 there were 32,129 persons $^{30}$.

\footnotetext{
${ }^{28}$ Пузирьов М.С. Диференціація та індивідуалізація виконання покарання у виді позбавлення волі на певний строк: дис. ... канд. юрид. наук: 12.00.08. Київ, 2012. С. 208.
} 
As you can see, the reduction in the number of convicts in correctional and juvenile correctional colonies was the basis for their optimization, which is confirmed by official statistics of the SCES of Ukraine, according to which convicts are not kept in 27 penal institutions now, due to optimization of their activities, namely: juvenile correctional colonies - 3; colony of maximum security level -1 ; colony of medium security level for recidivists -5 ; colony of medium security level for first-time convicts - 3; colony of minimum security level with general conditions (men) - 3; colony of minimum security level with general conditions (women) - 3; correctional centers -8 ; medical institution $-1^{31}$.

It is also appropriate to pay attention to the doctrinal preconditions for introducing the institute of multifunctional penal institutions, which are given in the scientific achievements of modern domestic researchers in the field of criminal and executive law. Thus, based on the results of studying national practice and foreign experience in the execution of sentences related to imprisonment, the proposal to establish multifunctional (universal) penitentiary institutions in Ukraine is supported by O.I. Kislov, O.A. Duka ${ }^{32}$, M.I. Lysenko ${ }^{33}$, M.S. Puzyrov ${ }^{34}$ and others.

The proposals formulated in this paragraph are the author's vision for some processes of reforming (developing) the penitentiary system of Ukraine with an emphasis on sentence enforcement in the form of deprivation of freedom for determined period. They do not cover all the issues arising in the process of implementation by the bodies and institutions of the Ministry of Justice of Ukraine of state policy in the field of execution of criminal penalties, the range of which is much wider and can't be included in one article, taking into account the requirements for its volume. This fact creates the prerequisites for further researches in this direction.

\footnotetext{
${ }^{29}$ Пузирьов М С. Реалізація виправними колоніями принципу диференціації та індивідуалізації виконання покарання у виді позбавлення волі на певний строк: монографія / за наук. ред. докт. юрид. наук, проф. I. Г. Богатирьова. Київ: ВД «Дакор», 2014. С. 6.

30 Загальна характеристика Державної кримінально-виконавчої служби України. URL : https://kvs.gov.ua/ 2020/harakteristika/01.02.2020.pdf (дата звернення: 20.05.2020).

31 Там само.

${ }^{32}$ Кіслов O.І., Дука О.А. Актуальні питання оптимізації структури та штату установ виконання покарань і слідчих ізоляторів. Актуальні питання застосування кримінально-виконавчого законодавства: матеріали круглого столу (Київ, 18 берез. 2015 р.) / відп. ред. В.А. Кирилюк. Київ : Ін-т крим.-викон. служби, 2015. С. 66.

33 Лисенко М.І. Ізоляція засуджених до позбавлення волі на певний строк у виправних колоніях : дис. ... канд. юрид. нау: 12.00.08. Харків, 2017. С. 173.

${ }^{34}$ Пузирьов М.С. Виконання покарання у виді позбавлення волі на певний строк у зарубіжних країнах: порівняльно-правове дослідженн я: дис. ... д-ра юрид. наук: 12.00.08. Ірпінь, 2018. С. 352-353.
} 


\section{CONCLUSIONS}

The analysis of current trends of reforming the system of sentence enforcement in the form of deprivation of freedom for determined period in Ukraine gives grounds to make the following conclusions and generalizations:

At the present stage of development of the criminal and executive legislation of Ukraine the process of sentence enforcement in the form of deprivation of freedom for determined period has the greatest degree of legal regulation, in comparison with other types of punishments. According to official statistics, this type of punishment is second only to criminal law sanctions such as release from probation and a fine. Among those punishments that take place in conditions of social isolation and are executed by the SCES of Ukraine (arrest, restriction of freedom, life sentence), deprivation of freedom for determined period takes the first place in quantitative terms.

The main source of criminal and executive legislation of Ukraine in the field of regulation of the procedure and conditions of sentence enforcement in the form of deprivation of freedom for determined period is the CEC of Ukraine adopted in 2003, which since its entry into force has passed three stages of improving its rules depending on the subject of state policy in the field of execution of criminal penalties.

Among the main ways of improving the institution of sentence enforcement in the form of deprivation of freedom for determined period at the present stage of reforming (developing) the Penitentiary System of Ukraine it is appropriate to highlight the following ones: 1) progressive implementing of the correctional paradigm of sentence enforcement in the form of deprivation of freedom for determined period by regulation and practical implementation of specific means of achieving the goal of the Penitentiary System in the form of protecting society from crime and focusing the Penitentiary System on person's re-socialization and re-integration; 2) improving the management structure of the Penitentiary System by creating a department (sector) for the execution of criminal penalties in each region; 3) scientifically substantiating and experimentally implementing of multifunctional penal institutions.

\section{SUMMARY}

Current trends of reforming the system of sentence enforcement in the form of deprivation of freedom for determined period in Ukraine are presented in the article. The urgency of studying this area of implementing the state policy in the field of execution of criminal punishments is preconditioned by both quantitative indicators of the practice of this type of punishment and the scope of legal restrictions applied to those sentenced to this measure of state coercion. It is emphasized that the complex criminogenic nature of convicts deprived of freedom 
for determined period necessitates a set of measures of socio-educational, psychological and preventive character, which can achieve their end result in case of progressive implementation by the Ministry of Justice and its bodies and institutions of the correctional paradigm of sentence enforcement process. In order to stimulate socially useful employment of convicts sentenced to imprisonment for determined period, one of the ways to improve the criminal and executive legislation of Ukraine is to supply it with norms that will provide a preferential procedure for crediting convicts involved in labor. Based on the analysis of the problems of modern management practice, it is substantiated that the optimal management structure of the Penitentiary System should provide for the establishment of a department (sector) for the execution of criminal penalties in each region, which would be subordinated to the relevant interregional department for the execution of criminal penalties of the Ministry of Justice. It is emphasized that in the specified structural subdivisions at the level of each region the positions of specialists should be provided not only in the direction of regime, protection and supervision, but also social-educational, psychological, operative-search, etc. This will allow for more consistent implementation in practice (by exercising control by the regional unit over specific areas of penal institutions) of the relevant tasks of the Ministry of Justice of Ukraine, its interregional (Department for the Execution of Criminal Punishments) and territorial bodies (5 interregional departments) policies in the field of execution of criminal punishments. It is noted that the rapid decrease in the number of convicts over the past 10 years has necessitated the optimization of the activities of a significant number of penal institutions, which has put on the agenda the study of experimental implementation of multifunctional penal institutions.

\section{REFERENCES}

1. Гритенко О.А. Теоретико-правові концептуальні засади прогресивної системи виконання та відбування покарання у виді позбавлення волі : дис. ... д-ра юрид. наук : 12.00.08. Одеса, 2020. 492 с.

2. Загальна характеристика Державної кримінально-виконавчої служби України. URL : https://kvs.gov.ua/2020/harakteristika/01.02.2020.pdf (дата звернення: 20.05.2020).

3. Кіслов О.І., Дука О.А. Актуальні питання оптимізації структури та штату установ виконання покарань і слідчих ізоляторів. Актуальні питання застосування кримінально-виконавчого законодавства: матеріали круглого столу (Київ, 18 берез. 2015 р.) / відп. ред. В.А. Кирилюк. Київ : Ін-т крим.викон. служби, 2015. С. 66-68.

4. Кримінально-виконавчий кодекс України : Закон України від 11.07.2003 p. № 1129-IV. Відомості Верховної Ради Украӥни. 2004. № 3-4. Ст. 21. 
5. Лисенко М.I. Ізоляція засуджених до позбавлення волі на певний строк у виправних колоніях : дис. ... канд. юрид. наук : 12.00.08. Харків, 2017. $218 \mathrm{c}$.

6. Олійник О.І. Загальна характеристика періодів становлення та розвитку кримінально-виконавчої системи і законодавства України. Кримінальновиконавчому кодексу України - 9 років: матеріали I міжнар. наук.-практ. конф. (Київ, 28 листоп. 2012 р.). Київ : Інститут кримінально-виконавчої служби, 2012. С. 14-17.

7. Про внесення змін до деяких законодавчих актів України щодо забезпечення виконання кримінальних покарань та реалізації прав засуджених: Закон України від 07.09.2016 p. № 1492-VIII. Відомості Верховної Ради України. 2016. № 43. Ст. 736.

8. Про внесення змін до деяких законодавчих актів України щодо забезпечення права засуджених i осіб, які тримаються під вартою, на листування 3 питань, пов'язаних 3 порушенням прав людини : Закон України від 01.12.2005 р. № 3166-IV. Відомості Верховної Ради Украйни. 2006. № 12. Ст. 103.

9. Про внесення змін до деяких законодавчих актів України щодо регулювання діяльності священнослужителів (капеланів) в органах та установах, що належать до сфери управління Державної пенітенціарної служби України : Закон України від 14.05.2015 р. № 419-VIII. Вiдомості Верховної Ради України. 2015. № 28. Ст. 254.

10. Про внесення змін до Кримінально-виконавчого кодексу України щодо забезпечення прав засуджених осіб в установах виконання покарань : Закон України від 21.01.2010 р. № 1828-VI. Відомості Верховної Ради України. 2010. № 12. Ст. 114.

11. Про внесення змін до Кримінально-виконавчого кодексу України щодо адаптації правового статусу засудженого до європейських стандартів : Закон України від 08.04.2014 p. № 1186-VII. Відомості Верховної Ради України. 2014. № 23. Ст. 869.

12. Про внесення змін до Кримінально-виконавчого кодексу України щодо вдосконалення порядку застосування до засуджених заходів заохочення і стягнення : Закон України від 06.09.2016 р. № 1487-VIII. Відомості Верховної Ради України. 2016. № 42. Ст. 699.

13. Про внесення змін до Кримінально-виконавчого кодексу України щодо гуманізації порядку та умов виконання покарань : Закон України від 06.09.2016 р. № 1488-VIII. Відомості Верховної Ради Украӥни. 2016. № 42. Ст. 700 .

14. Про внесення змін до Кримінально-виконавчого кодексу України щодо порядку та умов відбування покарання : Закон України від 
05.09.2013 р. № 435-VII. Відомості Верховної Ради Украӥни. 2014. № 20-21. Ст. 724.

15. Проект Закону про пенітенціарну систему: від 24.11.2017 p. № 7337. URL : http://w1.c1.rada.gov.ua/pls/zweb2/webproc4_1?pf3511=62965 (дата звернення: 20.05.2020).

16. Проєкт Закону України «Про пенітенціарну систему». Міністерство юстищії України: офіційний сайт. URL : https://minjust.gov.ua/m/13102020povidomlennya-pro-provedennya-publichnogo-gromadskogo-obgovorennyaproektu-zakonu-ukraini-pro-penitentsiarnu-sistemu (дата звернення: 18.11.2020).

17. Пузирьов М.С. Виконання покарання у виді позбавлення волі на певний строк у зарубіжних країнах: порівняльно-правове дослідження : дис. ... д-ра юрид. наук : 12.00.08. Ірпінь, 2018. 498 с.

18. Пузирьов М.С. Диференціація та індивідуалізація виконання покарання у виді позбавлення волі на певний строк : дис. ... канд. юрид. наук : 12.00.08. Київ, 2012. 252 с.

19. Пузирьов М.С. Реалізація виправними колоніями принципу диференціації та індивідуалізації виконання покарання у виді позбавлення волі на певний строк : монографія / за наук. ред. докт. юрид. наук, проф. І.Г. Богатирьова. Київ : ВД «Дакор», 2014. 300 с.

20. Судова статистика. Аналітичні огляди щодо стану здійснення правосуддя. Судова влада України. URL : https://court.gov.ua/inshe/sudova_ statystyka/ (дата звернення: 20.05.2020).

21. Яковець I.C. Теоретичні та прикладні засади оптимізації процесу виконання кримінальних покарань: монографія. Харків : Право, 2013. 392 с.

\section{Information about authors:} Vasylyk V. V.,

Deputy Minister of Justice of Ukraine

Ministry of Justice of Ukraine 13, Horodetskyi str., Kyiv, 01001, Ukraine

Oliinyk O. I.,

Ph. D. in Law, Associate Professor, First Vice-Rector Academy of the State Penitentiary Service 34, Honcha str., Chernihiv, 14000, Ukraine 